\title{
TEACHERS' WELLBEING: THE ROLE OF CALLING ORIENTATION, JOB CRAFTING AND WORK MEANINGFULNESS
}

\author{
Lana Jurčec, Tajana Ljubin Golub, \& Majda Rijavec \\ Faculty of Teacher Education, University of Zagreb (Croatia)
}

\begin{abstract}
People who consider their work as a calling find it fulfilling, purposeful, and socially useful, thus leading to higher levels of well-being. Since work is a central part of the identity of people with calling orientation and represents one of the most important domains of their lives, we assume that they are more prone to craft their job. They tend to make the physical and cognitive changes in the task or relational boundaries of their work in order to make it more meaningful. Both experiencing work as a calling and job crafting are found to be associated with numerous positive outcomes such as increased job satisfaction, psychological well-being and sense of meaning. This study adds to literature by exploring simultaneously the role of both calling orientation and job crafting in primary teacher's wellbeing.

The aim of the study was to explore the relationship between teachers calling orientation, job crafting, work meaningfulness and well-being. In light of the literature on work meaningfulness and psychological well-being, a serial mediation model was proposed with job crafting and work meaningfulness mediating the relationship between teacher calling orientation and teacher flourishing.

The sample consisted of 349 primary school teachers (95\% female) from public schools in northern western region of Croatia. They have on average 22 years of teaching experience (ranged from $0-43$ years). Self-report measures of calling orientation (Work-Life Questionnaire), job crafting (Job Crafting Scale), work meaning (Work Meaningfulness scale) and flourishing (Flourishing Scale) were used.

The findings revealed that the job crafting via increasing structural job resources mediated the relationship between calling orientation and work meaningfulness. Furthermore, the results supported the proposed serial mediation between calling orientation and flourishing via increasing structural job resources and increasing work meaningfulness.

Based on these findings, several practical implications can be noted. First, interventions aimed at helping teacher view their job as a calling should be promoted in schools. Second, teachers should be encouraged to cultivate job crafting as it is an important path to meaningfulness in work context and overall psychological wellbeing. This is specially the case for increasing structural job resources, such as autonomy and variety at work.
\end{abstract}

Keywords: Calling, flourishing, job crafting, teachers, well-being.

\section{Introduction}

Research suggests that people tend to frame their relationship to work in different ways: as job, career, and calling (Bellah, Madsen, Sullivan, Swidler \& Tipton, 2008; Wrzesniewski, 2003). For some employees' work is "just a job", a source of financial security and is not a central part of their identity. Some see their work as career and are focused on advancement and achievement of professional goals (Bellah et al., 2008; Wrzesniewski, 2003). They invest more in their professional identity than those with a job orientation. Finally, employees with a calling orientation view their work as a fulfilling and intrinsically rewarding, purposeful, and socially useful. Therefore, work is a central part of their identity and represents one of the most important domains of their lives (Bellah et al., 2008; Wrzesniewski, 2003; Wrzesniewski McCauley, Rozin, \& Schwartz, 1997). Although, all abovementioned work orientations were researched, majority of studies focused on the calling orientation (e.g. Harzer \& Ruch, 2012; Peterson, Park, Hall \& Seligman, 2009).

It is generally believed that teachers tend to experience their work as a calling more often than employees in other professions (e.g., Hagmaier \& Abele, 2012). Previous studies revealed that it is a rather frequent phenomenon, the percentage of teachers with calling orientation varying from $45 \%$ in United Kingdom to $83 \%$ in Croatia (e.g., Bullough \& Hall-Kenyon, 2012; Rijavec, Pečjak, Jurčec \& Gradišek, 2015). 
The relationship between calling orientation and various positive outcomes including well-being is well established. Calling orientation has been found to be positively related to life and job satisfaction, work and life meaning and zest (e.g., Duffy \& Dik, 2013; Duffy, England, Douglass, Autin, \& Allan, 2017). Several studies confirmed strong links of calling orientation and perception of meaningful work (e.g., Bunderson \& Thompson, 2009; Willemse \& Deacon, 2015). However, according to Work as Calling Theory (for review see Duffy, Dik, Douglass, England, \& Velez, 2018; Duffy, Douglass, Autin, England, \& Dik, 2016) calling and meaningful work each affect each other over time, meaning that perceiving a calling will lead to experience increased work meaning, which in turn will lead to an increased sense of living a calling and consequently to a positive outcome such as well-being. In calling theory both personal and contextual factors are highly relevant and if incongruence occur, person might promote the work meaningfulness through job crafting (Berg, Dutton, Wrzesniewski, 2013). Job crafting has been defined as process of self-initiated redefining and reimagining relational, behavioral, and cognitive work engagements in personally meaningful ways (Wrzesniewski \& Dutton, 2001). However, it is yet not clear which components of job crafting are most relevant for increasing work meaningfulness. In addition, there is no study researching the role of job crafting and meaningfulness as mediators in the relationship between calling and well-being.

Based on the above-mentioned research, we assume that teachers with calling orientation are more prone to craft their job thus making it more meaningful, which in turn, increase teacher's well-being.

\section{Objectives}

The central aim of this study is to examine the relationship between perceiving work as a calling, job crafting, work meaningfulness and well-being in primary school teachers. First, we aimed to investigate what job crafting dimensions mediate in the relationship between calling orientation and work meaningfulness. Second, we aimed to test whether job crafting and work meaningfulness mediates between calling orientation and flourishing.

\section{Method}

\subsection{Participants and Procedure}

The sample consisted of 349 primary school teachers (95\% female) from public schools in northern western region of Croatia. An average length of service was 22 years (ranged from 0-43 years of teaching experience). Questionnaires were administered during the primary teachers' professional meetings at the county level and lasted approximately 20 minutes. Participants were informed about the aim of the research, assured that all collected data would remain confidential, and used for research purposes only.

\subsection{Instruments}

Work-Life Questionnaire (Wrzesniewski et al., 1997) is a 3-item questionnaire measuring the attitude towards work. The questionnaire includes three brief scenarios, which describe individuals who approach work as a Job, a Career, and Calling. Each scenario is rated on a 4-point Likert scale to indicate their likeness to how similar they are to the person described (from 1 - not at all like me, through 4 - very much like me). In this study only the Calling scenario was used. Extract from the scenario (p. 24):

Person's work is one of the most important parts of his life. He is very pleased that he is in this line of work. He tends to take his work home with him and on vacations, too. He is very satisfied with his work and feels good about his work because he loves it, and because he thinks it makes the world a better place.

The job crafting scale (Tims, Bakker, \& Derks, 2012) was used for assessing job crafting scale. The scale measures four dimensions of job crafting using 21 items. The four scales are increasing structural job resources (e.g., "I make sure that I use my capacities to the fullest"), increasing social job resources (e.g., "I ask others for feedback on my job performance") increasing challenging job demands (e.g. "If there are new developments, I am one of the first to learn about them and try them out"), and decreasing hindering job demands (e.g., "I try to ensure that my work is emotionally less intense"). Respondents indicate how often they engaged in each of the behaviors on a 5-point Likert scale ranging from 1 (never) to 5 (very often).

Work Meaningfulness scale (Bunderson \& Thompson, 2009) measures perceived meaning at work with the five-item scale (e.g.," I have a meaningful job"). Individuals respond to each item on a 5-point Likert scale ranging from 1 (not at all through) to 5 (completely). Higher overall (average) score indicates greater work meaningfulness. 
Flourishing Scale (Diener et al., 2009) is an eight-item measure of positive human functioning. including perceived success in areas such as competence, engagement with daily activities, meaning and purpose in life, positive relationships, and optimism (e.g. "I am competent and capable in the activities that are important to me"). Participants rated items on a 7-point scale, ranging from 1 (strongly disagree) to 7 (strongly agree). Higher score indicates higher level of eudemonic dimensions of well-being. All scales were used previous in Croatian samples and shown adequate psychometric characteristics (Miljković, Jurcec, \& Rijavec, 2016; Rijavec et al., 2016; Vid, Glavaš, \& Rijavec, 2019).

\section{Results}

\subsection{Descriptive statistics and correlations}

The descriptive statistics and intercorrelations of all measured variables are presented in Table 1.

Table 1. The descriptive statistics and intercorrelations of calling work orientation, job crafting, work meaningfulness and flourishing.

\begin{tabular}{|c|c|c|c|c|c|c|c|}
\hline & 1. & 2. & 3. & 4. & 5. & 6. & 7. \\
\hline 1. Calling & & $.19^{* *}$ & $.23^{* *}$ & -.09 & .07 & $.40^{* *}$ & $.28^{* *}$ \\
\hline $\begin{array}{l}\text { 2. Increasing structural job } \\
\text { resources }\end{array}$ & & & $.59 * *$ & $.27 * *$ & $.19^{* *}$ & $.28 * *$ & $.46^{* *}$ \\
\hline $\begin{array}{l}\text { 3. Increasing challenging } \\
\text { job demands }\end{array}$ & & & & $.18^{* *}$ & $.33 * *$ & $.16^{* *}$ & $.31 * *$ \\
\hline $\begin{array}{l}\text { 4. Decreasing hindering } \\
\text { job demands }\end{array}$ & & & & & .01 & -.08 & .05 \\
\hline $\begin{array}{l}\text { 5. Increasing social job } \\
\text { resources }\end{array}$ & & & & & & .07 & $.16^{* *}$ \\
\hline $\begin{array}{l}\text { 6. Work meaningfulness } \\
\text { 7. Flourishing }\end{array}$ & & & & & & & $\begin{array}{c}.33 * * \\
-\end{array}$ \\
\hline Min - max & $1.00-5.00$ & $2.80-5.00$ & $1.00-5.00$ & $1.60-5.00$ & $1.00-5.00$ & $3.00-5.00$ & $2.50-5.00$ \\
\hline Cronbach's alpha & n.a. & .86 & .88 & .73 & .84 & .80 & .90 \\
\hline $\mathrm{M}$ & 3.42 & 4.28 & 3.35 & 3.16 & 2.83 & 4.71 & 5.83 \\
\hline SD & 0.75 & 0.54 & 0.78 & 0.64 & 0.73 & 0.37 & 0.77 \\
\hline
\end{tabular}

Note: ${ }^{*} p<.05 ;{ }^{* *} p<.01$

\subsection{Mediating role of job crafting dimensions in the relationship between calling orientation and work meaningfulness}

Parallel mediation analyses with four mediators using the PROCESS macro for SPSS were performed to test the hypothesized mediation role of job crafting dimensions in the relation between calling orientations and work meaningfulness. A Monte-Carlo (bootstrapping) approximation was obtained with 2000 bootstrap resamples (the 95\% confidence). The models tested job crafting dimensions as mediators between calling and work meaningfulness. Results confirmed only the partial mediating role of increasing structural job resources $(\mathrm{CI}=.11$ to .28$)$

Since only increasing structural job resources was found to mediate between calling orientation and work meaningfulness, we assessed the serial mediation of increasing structural job resources and work meaningfulness in the relationship between calling orientation and flourishing. Results confirmed the serial mediation $(\mathrm{CI}=.00$ to .02$)$ (Figure 1$)$.

Figure 1. Increasing structural job resources and work meaningfulness as mediators between calling orientation and flourishing.

$.18^{* *}$

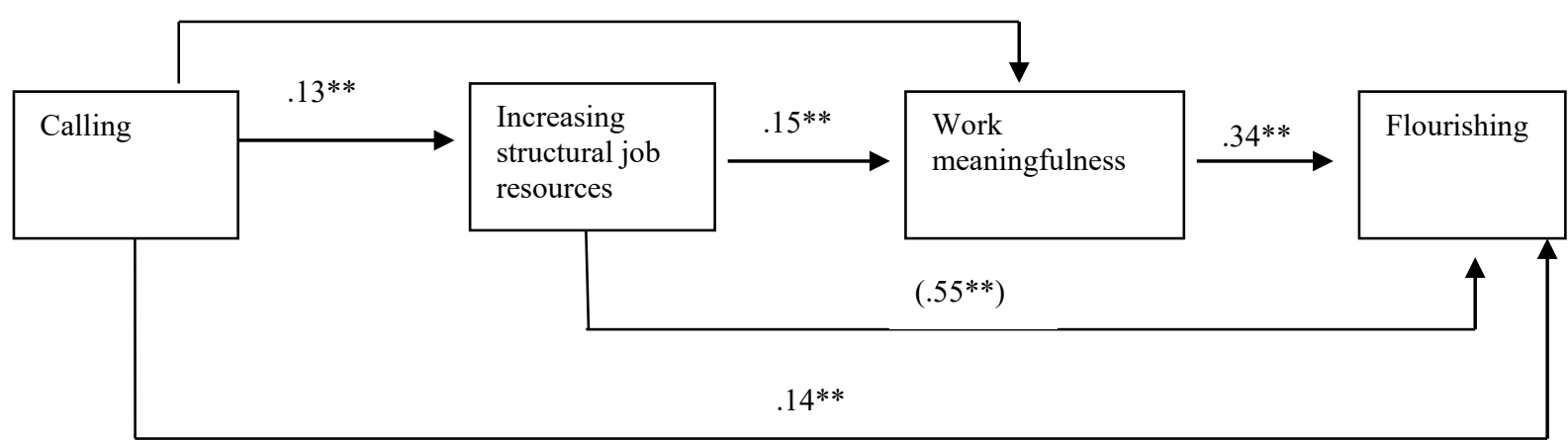

Note. Numerical values represent standardized path coefficients $(\beta) . P$-values: ${ }^{*} p<.05 ; * * p<.01 ; * * * p .001$. 


\section{Discussion}

This study proposed a model linking calling orientation with well-being. We hypothesized that both job crafting and work meaningfulness operate as mediators in the relationship between calling orientation and well-being. More specifically, it was proposed that perceiving work as a calling would lead to higher levels of job crafting, which in turn, would lead to the higher work meaningfulness and consequently higher flourishing.

Present study confirmed significant relationship between calling orientation and meaningful work as was expected by the previous studies (e.g., Bunderson \& Thompson, 2009; Duffy, Allan, Autin, \& Bott, 2013; Willemse \& Deacon, 2015). The results of parallel mediation analyses revealed that job crafting via increasing structural job resource partially mediated the relationship between calling orientation and work meaningfulness. Furthermore, results of serial mediation showed that increased structural job resources and work meaningfulness foster teacher's well-being. Findings suggest that a sense of calling leads teachers to craft their jobs by increasing structural job resources through creating opportunities for professional development (e.g., skills, talents, competencies) and autonomy which in turn fulfill their work with meaning and purpose. This finding is consistent with studies finding that job crafting (Tims et al. 2012; Slemp \& Vella-Brodrick, 2014) and meaningful work (Blake, Batz-Barbarich, Sterling, \& Tay, 2019; Miljkovic, et al., 2016) predicted well-being.

Recent research has found that key mechanisms in transferring one's calling into job crafting behavior are career commitment, occupational self-efficacy and job autonomy (Chang, Rui, \& Lee, 2020). Individuals who perceive their work as a calling are more aware of their goals and mission to achieve (Fried, Grant, Levi, Hadani, \& Slowik, 2007) and motivated to gain responsibility for their own career development (Hall \& Chandler, 2005) thus crafting their work to fit their capacities. This study found that increasing structural job resources leads to work meaningfulness which in turn transfers to higher wellbeing. On the other hand, increasing challenging job demands and social job resources were associated with higher flourishing, but these relationships were not mediated through work meaningfulness. Thus, these proactive work behaviors, as found in present study, directly and indirectly through making job more meaningful promote teachers flourishing. It is worth noting that decreasing hindering job demands was proactive behavior which was not related to teachers' wellbeing measured as flourishing. Further studies may investigate whether this component of proactive behavior is more related to lower level of work stress and burnout.

Limitation of the study includes teacher sample, and the study should be replicated with other samples of teachers. Besides corroborating the findings of this study, future study may further investigate the role of teachers age, work experience or organizational climate in school as possible moderator factors in the relationship between calling, job crafting behaviors and teachers' wellbeing. However, based on these findings, teachers should be encouraged to cultivate job crafting, especially structural job resources, as it is an important path to meaningfulness in work context and overall psychological well-being.

\section{References}

Bellah, R. N., Madsen, R., Sullivan, W. M., Swidler, A., \& Tipton, S. M. (1985). Habits of the heart. Berkeley: University of California Press

Berg, J. M., Dutton, J. E., \& Wrzesniewski, A. (2013). Job crafting and meaningful work. In B. J. Dik, Z. S. Byrne, \& M. F. Steger (Eds.), Purpose and meaning in the workplace (p. 81-104). American Psychological Association. doi:10.1037/14183-005

Blake A. A., Batz-Barbarich, C., Sterling, H. M. and Tay, L. (2019). Outcomes of Meaningful Work: A Meta-Analysis. Journal of Management Studies, 56(3), 500-528. doi:10.1111/joms. 12406

Bullough, R. V., Jr. \& Hall-Kenyon, K. M. (2012). On teacher hope, sense of calling, and commitment to teaching. Teacher Education Quarterly, 39(2), 7 - 27.

Bunderson, J. S., \& Thompson, J. A. (2009). The call of the wild: Zookeepers, callings, and the doubleedged sword of deeply meaningful work. Administrative Science Quarterly, 54(1), 32-57. doi:10.2189/asqu.2009.54.1.32

Chang, P. C., Rui, H., \& Lee, A. Y. (2020). How Having a Calling Leads to Job Crafting: A Moderated Mediation Model. Frontiers in psychology, 11, 1-11. doi:10.3389/fpsyg.2020.552828

Diener, E., Wirtz, D., Tov, W., Kim-Prieto, C., Choi, D., Oishi, S., \& Biswas-Diener, R. (2009). New measures of well-being: Flourishing and positive and negative feelings. Social Indicators Research, 39, 247-266. doi:10.1007/978-90-481-2354-4_12

Duffy, R. D., \& Dik, B. J. (2013). Research on calling: What have we learned and where are we going? Journal of Vocational Behavior, 83(3), 428-436. doi:10.1016/j.jvb.2013.06.006 
Duffy, R. D., Allan, B. A., Autin, K. L., \& Bott, E. M. (2013). Calling and life satisfaction: It's not about having it, it's about living it. Journal of Counseling Psychology, 60, 42-52. doi:10.1037/a0030635.435

Duffy, R. D., Dik, B. J., Douglass, R. P., England, J. W., \& Velez, B. L. (2018). Work as a calling: A theoretical model. Journal of Counseling Psychology, 65(4), 423-439. doi:10.1037/cou0000276

Duffy, R. D., Douglass, R. P., Autin, K. L., England, J., \& Dik, B. J. (2016). Does the dark side of a calling exist? Examining potential negative effects. The Journal of Positive Psychology, 11(6), 634-646. doi:10.1080/17439760.2015.1137626

Duffy, R. D., England, J. W., Douglass, R. P., Autin, K. A., \& Allan, B. A. (2017). Perceiving a calling and well-being: Motivation and access to opportunity as moderators. Journal of Vocational Behavior, 98, 127-137. doi:10.1016/j.jvb.2016.11.003

Fried, Y., Grant, A. M., Levi, A. S., Hadani, M., \& Slowik, L. H. (2007). Job design in temporal context: a career dynamics perspective. Journal of Organisational Behaviour, 28, 911-927. doi: $10.1002 /$ job.486

Hagmaier, T., \& Abele, A. E. (2012). The multidimensionality of calling: Conceptualization, measurement and a bicultural perspective. Journal of Vocational Behavior, 81(1), 39-51. https://doi.org/10.1016/j.jvb.2012.04.001

Hall, D. T., and Chandler, D. E. (2005). Psychological success: when the career is a calling. Journal of Organisational Behaviour, 26, 155-176. doi: 10.1002/job.301

Harzer, C., \& Ruch, W. (2012). When the job is a calling: The role of applying one's signature strengths at work. The Journal of Positive Psychology, 7(5), 362-371.

Miljković, D., Jurčec, L., \& Rijavec, M. (2016). The relationship between teachers' work orientations and well-being: mediating effects of work meaningfulness and occupational identification. In Z. Marković, M. Đurišić Bojanović \& G. Đigić (Eds.), Individual and Environment: International Thematic Proceedia (pp. 303-312). Niš, Serbia: Faculty of Philosophy. doi:10.1080/17439760.2012.702784

Peterson, C., Park, N., Hall, N., \& Seligman, M. E. P. (2009). Zest and work. Journal of Organizational Behavior, 30, 161-172. doi:10.1002/job.584

Rijavec, M., Pečjak, S., Jurčec, L., Gradišek, P. (2016). Money and Career or Calling? Intrinsic vs. Extrinsic Work Orientations and Job Satisfaction of Croatian and Slovenian Teachers. Croatian Journal of Education, 18(1), 201-223. doi:10.15516/cje.v18i1.1163

Slemp, G. R., \& Vella-brodrick, D. (2014). Optimising employee mental health: The relationship between intrinsic need satisfaction, job crafting, and employee well-being. Journal of Happiness Studies, 15(4), 957-977. doi:10.1007/s10902-013-9458-3

Tims, M., Bakker, A. B., \& Derks, D. (2012). Development and validation of the job crafting scale. Journal of Vocational Behavior, 80, 173-186. doi:10.1016/j.jvb.2011.05.009

Vid, I., Glavaš, D., \& Rijavec, M. (2019, December 12-14). Uloga preoblikovanja posla u odnosu između proaktivne ličnosti $i$ dobrobiti, zadovoljstva poslom i zanesenosti na poslu [The role of job crafting in the relationship between proactive personality and well-being, job satisfaction and work related flow] [Poster presentation]. 2nd International Scientific Conference Brain and Mind: Promoting Individual and Community Well-Being, Zagreb, Croatia. https://www.unicath.hr/conference 2019-psychology

Willemse, M., \& Deacon, E. (2015). Experiencing a sense of calling: The influence of meaningful work on teachers' work attitudes. SA Journal of Industrial Psychology, 41(1), 1-9. doi:10.4102/sajip.v41i1.1274

Wrzesniewski, A. \& Dutton, J. E. (2001) Crafting a Job: Revisioning Employees as Active Crafters of Their Work. Academy of Management Review, 26(2), 179-201. doi: 10.2307/259118

Wrzesniewski, A. (2003). Finding positive meaning in work. In K. S. Cameron, J. E. Dutton, \& R. E. Quinn (Eds.), Positive organizational scholarship: Foundations of a new discipline (pp. 296-308). San Francisco: Berrett- Koehler.

Wrzesniewski, A., McCauley, C. R., Rozin, P. \& Schwartz, B. (1997). Jobs, careers, and callings: people's relations to their work. Journal of Research in Personality, 31, 21-33. doi:10.1006/jrpe.1997.2162 